needs that one who deceives will always find one who allows himself to be deceived" (1186). Seamon is right to suggest that the text in my reading is not the most efficient instrument of revenge, but I do not number revenge among the author's intentions; instead, I argue that it would be odd if Machiavelli had gone out of the way to help the Medici while attempting to further his own personal and civic ambitions.

Seamon suggests, enigmatically, that "any work that is not trivially correct is bound to be flawed in one way or another." But in the absence of some such reading as mine, we are left with the paradox of a work of patent genius riddled by disabling contradictions: all individuals look out for themselves, but the prince should seek disinterested and selfless counselors; princes who come to power aided by fortune and the arms of others fall easily, but only extraordinarily bad luck dooms Cesare Borgia, who came to power in just this way; one can control fortune by adapting to the times, but extensive reading and practical experience have shown Machiavelli no examples of adaptability. My model of a strategy of multiple intentions allows one to read the work as neither trivially correct nor significantly flawed.

Seamon claims that my interpretion is underwritten by the specious "blank check of current interpretation," that which "can be read" in a text, but he offers no response to my detailed arguments for the manner in which the text invites my interpretation. My reading may eventually prove faulty, but it is not kited; it is underwritten by evidence from The Prince itself and from Machiavelli's letters, diplomatic dispatches, poetry, and drama. Seamon does not mention my discussion of the Discourses, where Machiavelli, having repeated point by point the argument on fortuna in The Prince, adds explicitly what was already implicit in the handbook: there is no shelter from adverse fortune for the prince-only republics, which are able to draw as they need to on the diverse natures of their leading citizens, can adapt to changing times. I agree with Seamon that cultural critics' portraying "the potency of dominant ideologies" in a way that might make "resistance seem well-nigh impossible" is no reason to read the critics as advocates of the status quo, but Machiavelli makes explicit in the Discourses that resistance to fortune is impossible for the prince. While Seamon suggests that I "transpose . . to an intentionalist register" deconstruction's strategy of "systematic misreading of unintended implications," he has not addressed my argument for the manner in which Machiavelli provides for, and depends on, the systematic misreading of his text by gullible readers.
Seamon's criticism seems most on target when he suggests that the book I construct is "one made for professors, not the Medici." I do note in my conclusion that "Machiavelli outfoxed ... himself" with his "overly ingenious plan" (1193). Lorenzo Medici went hunting with his new brace of dogs, leaving The Prince, for better or for worse, to readers who are not princes. If forced to choose between my own impractically ingenious Machiavelli and Seamon's "naively idealistic" one, I would stick to my guns.

STEPHEN M. FALLON

University of Notre Dame

\section{Tracking a Seventeenth-Century Midwife}

To the Editor:

In the beginning of "Milton's Ganymede: Negotiations of Homoerotic Tradition in Paradise Regained" (106 [1991]: 262-76), Gregory W. Bredbeck makes some connection between Milton and a pamphlet attacking Elizabeth Cellier (263), which Bredbeck lists under Works Cited as a 1641 publication titled To the Praises [recte "Praise"] of Mrs. Cellier, the Popish Midwife. In the Forum of the October 1991 issue, Anne Barbeau Gardiner states that Cellier flourished around 1679-88 and hence could not have been attacked in print in 1641 or even in Milton's lifetime. Bredbeck's reply in the same Forum is that there is a broadside account "of the Cellier controversy dated 1641 , and this date has been transferred in pencil to two other accounts, all of which are bound in the British Library ..." (1178).

Bredbeck is not familiar with the scholarship on Cellier. The sketch of her in the Dictionary of National Biography lists nine items in its bibliography. Gardiner adds additional information in her edition of Cellier's 1680 tract, Malice Defeated (Augustan Reprint Soc., nos. 249-50, 1988), but the fullest account is in Antonia Fraser's The Weaker Vessel (London: Weidenfeld, 1984, 454-62). Cellier was born Elizabeth Marshall, in Canterbury. First, she married an English merchant; her second husband deserted her and went to Barbados; and her third marriage was to Pierre Cellier, a French businessman. Hence a tract of 1641 could not have named her "Mrs. Cellier." At her trial in 1680, the king pressed her to tell a "bawdy" story. As good King Charles II was not noted for his interest in elderly women, Cellier might not even have been born as early as 1641 . 
Here follow excerpts of two letters to me from officials in the British Library Bibliographical Information Service about the library's holdings of the tract To the Praise:

February 12, 1992 I have consulted both copies of To the praise of Mrs. Cellier the Popish midwife; on her incomparable book. London: Printed for Walter Davis in Amen-Corner, 1680 (British Library shelfmarks: C.20.f. 2 (133) and Lutt.III. 130) Both are dated: MDCLXXX. The item at Lutt, III, 130 also has 14. Sept. 1680 in manuscript above the main body of the text.

July 9,1992

I regret that it has still not been possible to trace the volume of broadsides allegedly containing To the Praise of Mrs Cellier, dated 1641, to which G.W. Bredbeck refers. My colleague in the Library's Antiquarian English section informs me that there is no record of a further acquisition of the pamphlet; it seems therefore most unlikely that $\mathrm{Mr}$ Bredbeck would have been given an uncatalogued copy of it.

In conclusion, there was no "Mrs. Cellier" who could have been mentioned in a work printed in 1641, and there is no connection with Milton at all. Furthermore, any allegations or accusations made in a work printed in 1680, Catholic or Protestant, in the frenetic atmosphere of the Titus Oates Plot and the Exclusion Crisis, are suspect.

ARTHUR H. SCOUTEN University of Pennsylvania

\section{Reply:}

Believing as I do that Arthur H. Scouten's several letters about the one sentence in question are motivated by his history at the University of Pennsylvania, my alma mater, and being unwilling as I am to participate in histories that are not my own, I simply note here that Scouten reiterates a point I acknowledge in my previous Forum response: the Cellier incident is, in actuality, of no interest to me. Indeed, the longer and more recent version of the essay, which appears in my book Sodomy and Interpretation: Marlowe to Milton (available from Cornell University Press at a very affordable price), entirely omits the single erroneous sentence.

GREGORY W. BREDBECK University of California, Riverside

\section{Science and Metaphor}

To the Editor:

As a rhetorician of science and a former scientist, I welcome Liliane Papin's thoughtful discussion of the metaphoric nature of science " "This Is Not a Universe: Metaphor, Language, and Representation," 107 [1992]: 1253-65). Especially important is her consideration of the plurality exemplified by Bohm and Peat's vision in which scientific metaphor appears at the pulse of the simultaneity of the is and the is not, what Ricoeur calls the "primordial dialectic." Papin's interweaving of quantum theory, literary criticism, Zen koans, and the $I$ ching is particularly relevant in that each approach moves toward an integral view. But, as Papin points out in alluding to Whorf's work, Indo-European languages obscure an integral view of nature since they separate noun from verb, subject from event, self from action. In the multiple universe Papin describes, we are inseparable from our thoughts, words, and actions. And, yes, words are traps because no one can capture the dynamic unity of nature in any one metaphor, phrase, or theory. All we can do is evoke the sense of change, the trace of awakening that led to insight.

"This is not a universe," Papin quotes from Bohm and Peat, who warn that once we name an object, we necessarily fragment our understanding of it. However limited our understanding may be, our words are still very powerful. Science may be akin to metaphor, but scientific theory is translated through technology into action. A vaccine, a bridge, an automobile - all these events change nature just as surely as do recycling aluminum cans, slashing and burning the rain forest, and reintroducing a red wolf into a wildlife preserve. Burying a missile in the earth affects nature, and so does planting a wheat field. Science is therefore operative metaphor. Words may be an important means to express a view of nature, but they do not exist alone, separate from the things they seek to describe. Rather, as Bohm suggests, nature responds according to the way we perceive, describe, experiment. If tested as a particle, light is a particle. If tested as a wave, light is a wave. But untested, is light particle or wave or nothing? How do we know? Is there a way to perceive this magnificent nothing?

Perhaps at the threshold of metaphor there is a clue to what lies beyond the poles of contrast, for a metaphor embodies the similarity in two things apparently dissimilar. Aristotle calls metaphor an "intuitive perception," and, in the Posterior Analytics, he says that intuition is more accurate than scientific knowl- 